\title{
Towards Ecological Green Buildings
}

\author{
Shaikh Javaria Manzoor ${ }^{1, *}$, JaeSeung Park ${ }^{2}$ \\ ${ }^{1}$ Hanyang University ERICA campus, Korea \\ ${ }^{2}$ School of Architecture, Professor Hanyang University ERICA campus, Korea \\ *Corresponding Author: javeria@hanyang.ac.kr
}

Copyright (C) 2014 Horizon Research Publishing All rights reserved.

\begin{abstract}
This paper has taken into account analysis of three case studies of Eco-Houses selected on the bases of fenestration insulation; designed with considerations of energy efficiency and traditional principals; which has been examined in regard with economy, material, and techniques. It is normally believed that closely controlled conditions equate with better comfort. Analysis of field surveys and adaptive comfort theories have made it clear that while closely controlled is one way of achieving comfort it is not the only way. It is a comparison of two types of houses. Firstly there is a complete analysis of an existing house in University of engineering and technology (U.E.T) staff colony that adopts traditional methods of achieving comfort through energy consumption. On the other hand there is another house where comfort levels are accommodated through alternative means. The calculations are made on the basis of utility bills. The latter house is an Eco-House design proposal for which creative design decisions are discussed in detail namely, selection of material, comfort levels, space utilization, and site development; according to the sun path diagrams. This Eco-House is based on precedent conducted studies. It is supposed to be within usual comfort limits by the use of shading and thermal mass to control the range of the temperature. The two prong strategy was devised for both the houses, separately. A comparative analysis of the radiation penetration through fenestrations for the two houses was conducted on two typical days. One is the longest day of the year i.e. 22nd of June and the other is the shortest day of the year i.e. 22nd of December. In closely controlled case firstly the analysis was made creating model based graphs of radiation statistics. And secondly for the same conditions ECOTECT software was used to study the sun path patterns and sunlight penetrations. The results obtained provide us the substance to statistically show the benefits of low energy designs. Moreover, the findings highlight an importance by providing an insight for the architects to pay attention towards as well as adopt the measures for designing low energy buildings.
\end{abstract}

Keywords Ecological, Sustainable

\section{Introduction}

The single major point discussed; in this paper; is to design energy efficient houses i.e. Eco Houses. Not only this will prove to be an economic and viable solution for the rising energy demands for houses, but this will suffice the occupants" natural quest for environmental friendly and landscaped houses. Although the term Eco is increasingly becoming predominant, this is not a new phenomenon.

This paper has taken examples from Lahore; the metropolitan city of Pakistan biggest province Punjab. The reason for opting Lahore is because; due to living in the nearby vicinity; the writer had enough access and sufficient resources towards completing this article.

The world is facing depleting energy crisis. It is especially important for a developing country like Pakistan to conserve and efficiently use the scarce energy resources. This article has statistically proved that of all the other major energy consumption means for domestic sector, the Eco houses is the best solution to design economical houses in order to reduce the energy bills. This paper has highlighted various aspects for the architects to ponder upon and thereby recommending them to consider or start designing such houses. To strengthen this idea the article was primarily focused upon the residential sector. It is due to the fact that the residential sector in Pakistan is the most energy consuming sector; according to the statistics provided by WAPDA; the country's largest public sector power company. Moreover because every individual spends most of the part of their day in the houses, therefore, the study was focused on the residential sector, and thus all the three examples are from three separate residential houses.

The efforts have been made to provide an in-depth insight for the readers on how to design Eco houses. The supporting case studies from different countries as well as the use of software ECOTECT add to the beauty of the context. 


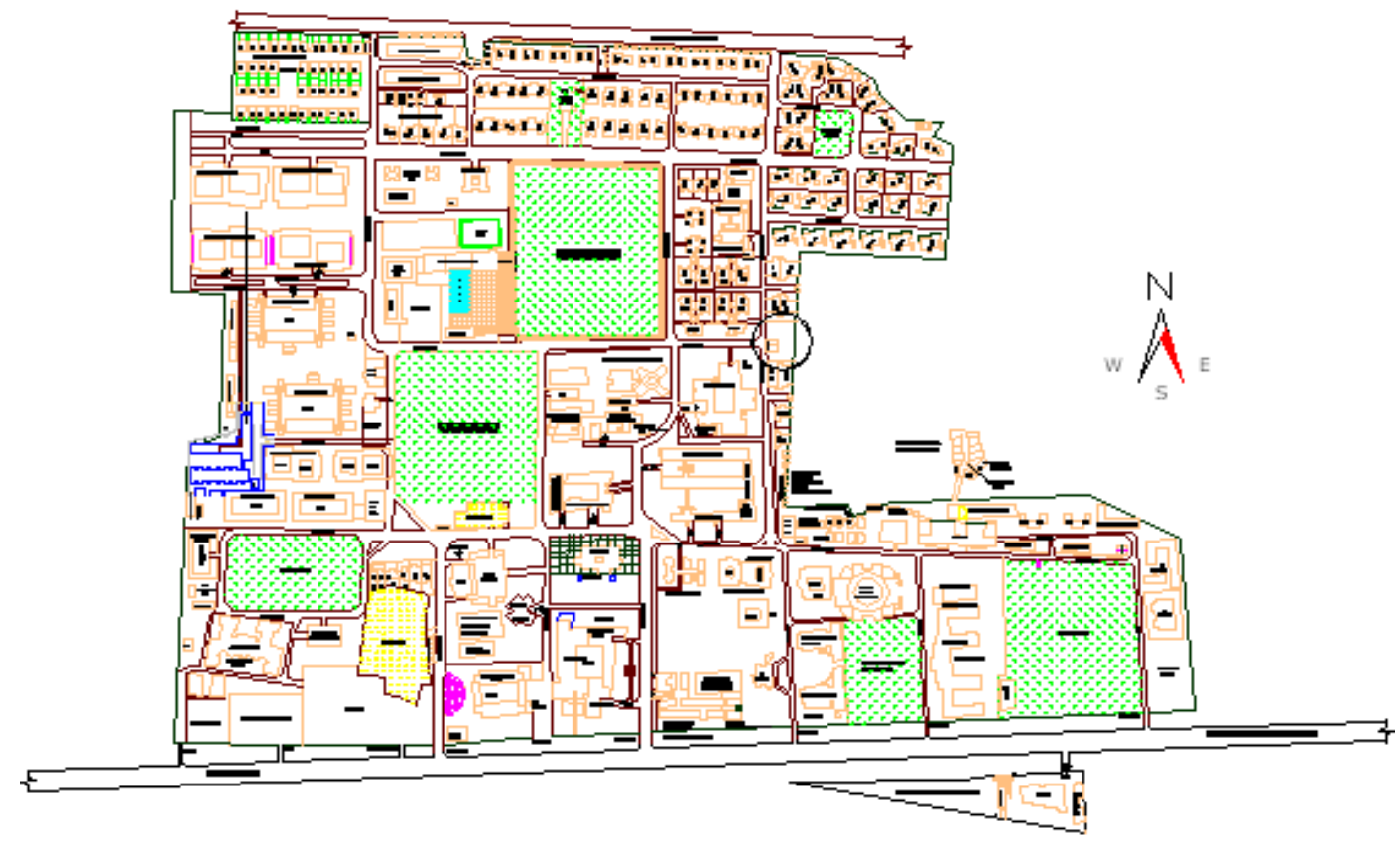

Figure 1. Site of UET

\section{Materials and Methods}

The discussion below explicitly reveals the methodology used for this research. It can be summarized as:

1. Taking the existing plans of typical houses at U.E.T

Figure1, comparing the energy consumption by analyzing the utility bills.

2. Redesigning the house to minimize the energy consumption

3. Calculating and comparing the radiation penetration through fenestrations

4. Calculating the energy loads on ECOTECT software for the new design

Rapid societal change means that designers must switch more and more from arbitrary creativity to focused invention. With shorter amount of time to solve increasingly complex problems, a systematic process is necessary if ideas are to be produced on purpose ${ }^{1}$. Thus, the logical sequence for decision process of this article comprises as below:

- Identify the problem to be solved

- Gather information

- Analyze the data

- Produce alternative solutions

- Evaluate ideas and allow time for additional ideas to occur

- Synthesize ideas into a whole

- Verify the proposed solution through evaluation ${ }^{2}$

The study is primarily based upon the residential sector low energy architecture design. The issue of comfort is often directly related to the energy consumption i.e. higher energy consumption, higher the comfort level. This article however, shows that although high energy consumption is one way of achieving comfort it is not the only way. There are other unexplored or less utilized alternatives available; some of them are discussed in this study. This article shows another way of attaining comfort levels i.e. by constructing the Eco House. It is basically a comparison of two houses of a residential colony of UET Lahore. First house is already built and the data is gathered from the existing facts collected for statistical analysis. The second house is an Eco-House; a purpose-built model that can be used as a proposed design for the futuristic constructions. Both the houses are similar i.e. their architecture, their number of inhabitants, income groups, life styles, and the energy consumption patterns; all of them have been chosen to have a similarity before the start of, and during the time period of this study.

"Eco-House" is an energy efficient home which uses the surrounding natural resources to heat, cool, and power all of its major energy needs. The home should employ a variety of alternative energy technologies, such as solar panels, a wind turbine, and battery packs to meet the energy needs of sustainable living. This article highlights the importance of the ecological architecture, to optimize comfort, and minimize energy consumption; by taking an example of a house of UET staff colony. The reduced energy consumption is found to be half or even less than half of the amount consumed by the comparative house.

Along with others, the study has taken into account three case studies of different traditional but eco houses. The first case study is of a house situated in the same city of Lahore. This house has used water circulation and air circulation by absorbing the external heat and ultimately cooling it before being circulated inside the premises. Also the external walls of the houses were more than 80 percent covered with greenery and landscape. The second case study is of a house in Iran that has open-able double roofs. The roofs open up in winter for sunlight penetration, whereas in summer they can be closed as an insulation against the strong beams of 
incoming sunlight radiation. The third and the last case study is of an American house. The shading devices of the western windows of the house are designed in such a way that they can adjust themselves according to the angle of the sun automatically; throughout the day and throughout the year Moreover this house is made up of several portable components that were carried individually to the site to be assembled ultimately as one cohesive unit within two days.

Furthermore, to demonstrate, simulate and analyze the environmental performance of buildings a software named ECOTECT is used. The basic function of the software is analysis of different elements namely, solar, thermal, acoustics, and lighting. Also it conducts the thermal simulations on the models of the buildings.

\subsection{Sunlight}

Sun is the brightest star in the solar system. It gives us light which is a valuable source of heat energy. It can be considered as the „life blood" for all living things on the planet and without which, almost all the living organisms would fail to exist.

The sun also creates few problems for living beings. For example, extreme heat which is often undesirable for it causes an increase in temperature. Therefore people have found ways over time to use the power of sun and reduce its negative effects. Nevertheless, the architects have also played role in maneuvering this source intelligently (Sustainable Design Guide, 2008) ${ }^{1}$.

\subsection{Radiation}

The architects can best utilize the sunlight by minimizing the radiation effects. It is the ultraviolent radiant energy emitted by Sun as a result of its nuclear fusion reactions. When this ultraviolent radiation is not absorbed by the atmosphere or other protective coating, it can cause adverse effects for humans in general and the overall climate in particular.

Unless it is properly calculated, it would be difficult to minimize the radiation. For the purposes of this article, the calculations on the longest day of the year i.e. June 22nd and the shortest day of the year i.e. December 22nd were made. These calculations were subject to the orientations of the building.

\subsection{Solar intensity on a Surface}

The angle the sun rays make with a surface will determine how much energy the surface receives. Since solar radiation comes to earth in essentially parallel rays, a surface that is perpendicular to those rays will intercept the greatest amount of energy. As the sun "s ray"s move away from being perpendicular, the energy intercepted by the surface will decrease.

However, a surface can be facing as much as $25 \%$ away from perpendicular to the sun and still intercept over $90 \%$ of the direct radiation. The angle that the rays of the sun make with a line perpendicular to a surface called the angle of incident will determine the percentage of the direct sunshine intercepted by the surface. Table 1 lists the percentage of sunshine intercepted by the surface for the different incident angle.

The Table 1 shows the energy consumption by house P-120. It is extremely higher than the second one. Although the average temperature varies for the different calendar months yet, it can clearly be seen what happens when the month changes. The variable nature of the average also makes it more responsive and compatible with dynamic thermal simulation.

The orientation of one of the house P-120 is East-West that is longitudinally placed, wherein the private zone is located in the east. There is a playground which has no trees and because of that all the sunlight directly enters into the house. The Figure 2 shows, where the sun rises from and sets to; the yellow line shows the path of the sun. The house touches two roads, because of that the intensity of sun increases. This house is a corner house, hence it faces sun, throughout the day, and there is no prevention which causes the house to consume too much electricity for the attainment of the comfort level inside the house.

The house shown in Figure 2; facing the sun though out the day; has the fenestration of almost $10 \mathrm{~m}^{2}$ on every elevation. The front elevation faced west; where there is living room located; faces sun in the evening hour. As a result the occupants use more electricity to obtain appropriate temperature inside.

Table 2 shows the energy consumption by house R-50. It is extremely lower than the first one. Although the average temperature varies for the different calendar months yet, it can clearly be seen what happens when the month changes. In the table and in the subsequent graph 4, it is shown that the monthly electricity bills of June and July are extremely lower i.e. Rs. 1143 and Rs. 1343 respectively.

There are a set of 12 tables given below, showing radiation penetration calculation. The calculations; made with regard to each separate elevations i.e. East, South, West and North respectively; were conducted on two particular days of the year namely, one is the longest day of the year; June $22^{\text {nd }}$ and the other is the shortest day of the year; December $22^{\text {nd }}$. The calculations of both of the days provide us an average for the whole year. The calculations for all the tables as well as the graphs are based upon the formulas discussed in chapter two. They also tell us about for how many number of hours the elevation faces the sun.

It is clearly shown in the table 5, that the eastern elevation faces maximum sun in the morning timings .i.e. before 12:00 p.m. The glazing size is $10 \mathrm{~m}^{2}$ on this elevation and the radiation penetration is maximum approximately 4500 $\mathrm{W} / \mathrm{m}^{2}$.

This is considered as extremely high and thus to prevent from heat this house uses immense amount of electricity for air-conditioning. 
Table 1. the house which conserve maximum energy

A house which faces the sun constantly Effects clearly indicated in the electric bills

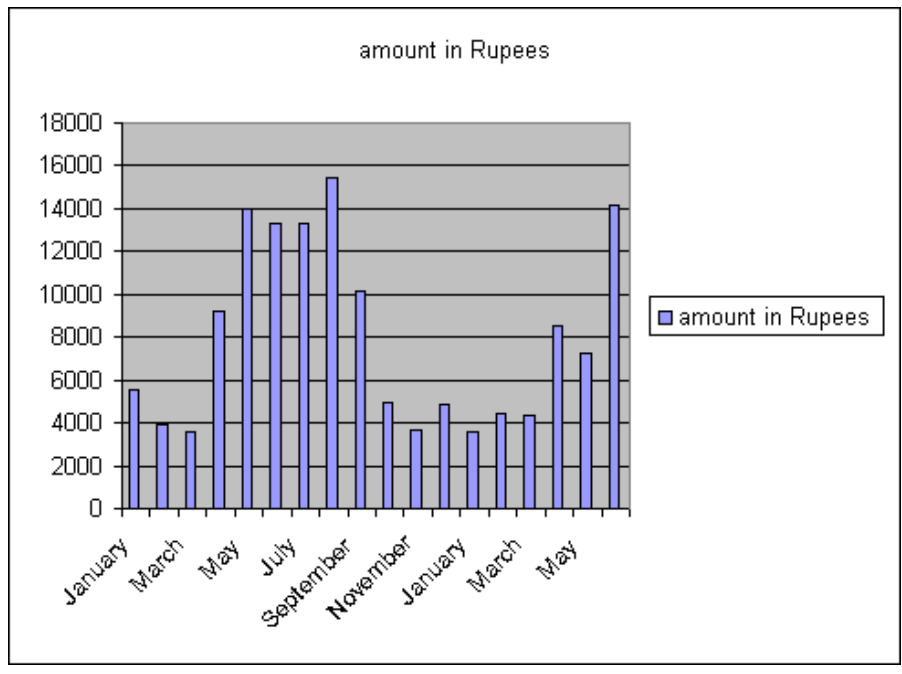

\begin{tabular}{|l|r|}
\hline \multicolumn{2}{|l|}{ Dr. Fazelat Tahira } \\
\hline 2007 & \multicolumn{1}{|c|}{ Amount } \\
\hline January & 5521 \\
February & 3892 \\
March & 3562 \\
April & 9177 \\
May & 13948 \\
June & 13312 \\
July & 13274 \\
August & 15459 \\
September & 10181 \\
October & 4933 \\
November & 3686 \\
December & 4842 \\
January & 3623 \\
February & 4455 \\
March & 4319 \\
April & 8502 \\
May & 7211 \\
June & 14194 \\
\hline
\end{tabular}

This house conserves maximum electricity since it is facing maximum sun

This house conserves minimum e lectricity since it is facing minimưm sun This house conserves maximum electricity since it is facing maximum sun

Figure 2. site plan of the houses 
Table 2. house shown in green

\section{A house which faces away from the sun}

\section{Effects clearly indicated in the electric bills}

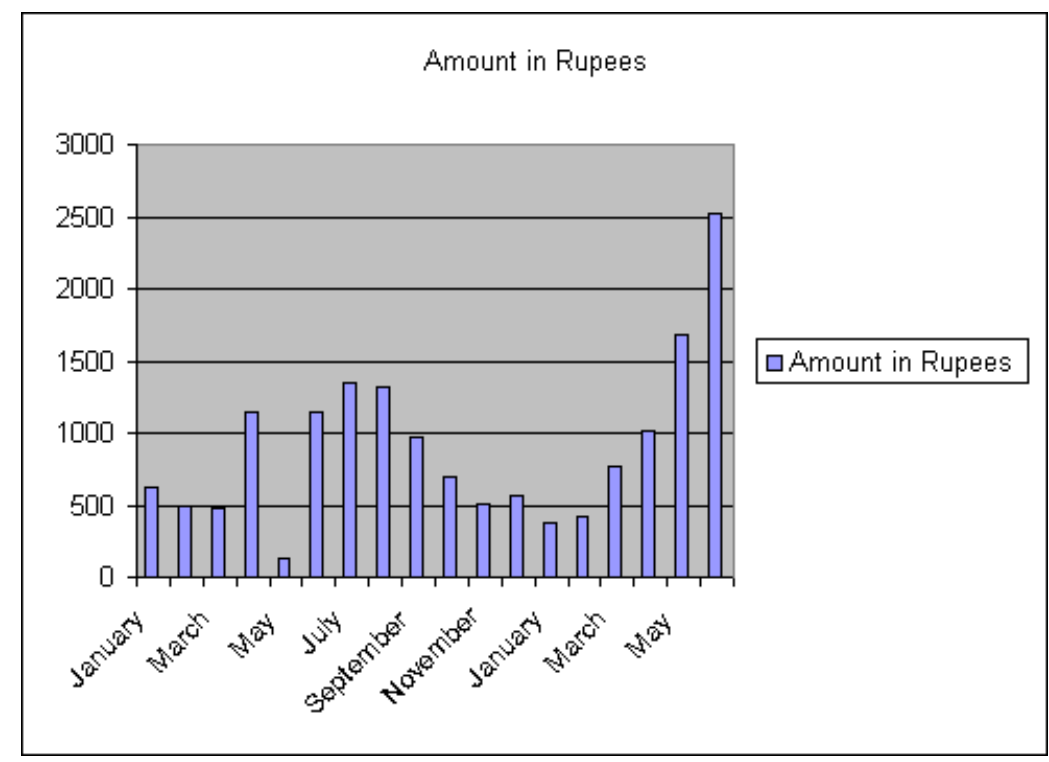

\begin{tabular}{|l|r|}
\hline \multicolumn{2}{|c|}{ Dr. Mohammad llyas } \\
\hline \multicolumn{1}{|c|}{2007} & \multicolumn{1}{|c|}{ Amount } \\
\hline January & 620 \\
February & 494 \\
March & 485 \\
April & 1143 \\
May & 130 \\
June & 1143 \\
July & 1343 \\
August & 1314 \\
September & 971 \\
October & 694 \\
November & 512 \\
December & 564 \\
January & 382 \\
February & 425 \\
March & 769 \\
April & 1018 \\
May & 1684 \\
June & 2526 \\
\hline
\end{tabular}

Table 3. Window one June 22. West Facing

\begin{tabular}{|c|c|}
\hline timing & day light through window \\
\hline $7: 00 \mathrm{AM}$ & \\
8:00 AM & \\
9:00 AM & \\
$10: 00 \mathrm{AM}$ & \\
$11: 00 \mathrm{AM}$ & $12: 00 \mathrm{PM}$ \\
$12: 00 \mathrm{PM}$ & $1: 00 \mathrm{PM}$ \\
$1: 00 \mathrm{PM}$ & $2: 00 \mathrm{PM}$ \\
$2: 00 \mathrm{PM}$ & $3: 00 \mathrm{PM}$ \\
$3: 00 \mathrm{PM}$ & $4: 00 \mathrm{PM}$ \\
$4: 00 \mathrm{PM}$ & $5: 00 \mathrm{PM}$ \\
$5: 00 \mathrm{PM}$ & $6: 00 \mathrm{PM}$ \\
$6: 00 \mathrm{PM}$ & $7: 00 \mathrm{PM}$ \\
$7: 00 \mathrm{PM}$ & $8: 11 \mathrm{PM}$ \\
$8: 00 \mathrm{PM}$ & \\
\hline
\end{tabular}

Table 4. Window one Dec 22

\begin{tabular}{|c|c|}
\hline timming & day light through window \\
\hline 7:00 AM & \\
\hline 8:00 AM & \\
\hline 9:00 AM & \\
\hline 10:00 AM & \\
\hline 11:00 AM & \\
\hline 12:00 PM & 12:00 PM \\
\hline 1:00 PM & 1:00 PM \\
\hline 2:00 PM & 2:00 PM \\
\hline 3:00 PM & 3:00 PM \\
\hline 4:00 PM & 4:00 PM \\
\hline 5:00 PM & 5:04 PM \\
\hline 6:00 PM & \\
\hline 7:00 PM & \\
\hline 8:00 PM & \\
\hline
\end{tabular}


Table 5. South window two June 22

\begin{tabular}{|c|c|}
\hline timing & day light through window \\
\hline $7: 00 \mathrm{AM}$ & \\
$8: 00 \mathrm{AM}$ & \\
9:00 AM & \\
$10: 00 \mathrm{AM}$ & \\
$11: 00 \mathrm{AM}$ & \\
$12: 00 \mathrm{PM}$ & $12: 00 \mathrm{PM}$ \\
$1: 00 \mathrm{PM}$ & $1: 00 \mathrm{PM}$ \\
$2: 00 \mathrm{PM}$ & $2: 00 \mathrm{PM}$ \\
$3: 00 \mathrm{PM}$ & $3: 00 \mathrm{PM}$ \\
$4: 00 \mathrm{PM}$ & $4: 00 \mathrm{PM}$ \\
$5: 00 \mathrm{PM}$ & $5: 00 \mathrm{PM}$ \\
$6: 00 \mathrm{PM}$ & $6: 00 \mathrm{PM}$ \\
$7: 00 \mathrm{PM}$ & $7: 00 \mathrm{PM}$ \\
$8: 00 \mathrm{PM}$ & $8: 11 \mathrm{PM}$ \\
\hline
\end{tabular}

Table 6. South window two Dec 22

\begin{tabular}{|c|c|}
\hline timing & day light through window \\
\hline 7:00 AM & \\
8:00 AM & \\
9:00 AM & \\
10:00 AM & \\
11:00 AM & $12: 00 \mathrm{PM}$ \\
$12: 00 \mathrm{PM}$ & $1: 00 \mathrm{PM}$ \\
$1: 00 \mathrm{PM}$ & $2: 00 \mathrm{PM}$ \\
$2: 00 \mathrm{PM}$ & $3: 00 \mathrm{PM}$ \\
$3: 00 \mathrm{PM}$ & $4: 00 \mathrm{PM}$ \\
$4: 00 \mathrm{PM}$ & $5: 04 \mathrm{PM}$ \\
$5: 00 \mathrm{PM}$ & \\
$6: 00 \mathrm{PM}$ & \\
$7: 00 \mathrm{PM}$ & \\
$8: 00 \mathrm{PM}$ & \\
\hline
\end{tabular}

Table 7. South window one June 22

\begin{tabular}{|c|c|}
\hline timing & day light through window \\
\hline 7:00 AM & \\
$8: 00$ AM & \\
$9: 00 \mathrm{AM}$ & \\
$10: 00 \mathrm{AM}$ & \\
$11: 00 \mathrm{AM}$ & $12: 00 \mathrm{PM}$ \\
$12: 00 \mathrm{PM}$ & $1: 00 \mathrm{PM}$ \\
$1: 00 \mathrm{PM}$ & $2: 00 \mathrm{PM}$ \\
$2: 00 \mathrm{PM}$ & $3: 00 \mathrm{PM}$ \\
$3: 00 \mathrm{PM}$ & $4: 00 \mathrm{PM}$ \\
$4: 00 \mathrm{PM}$ & $5: 00 \mathrm{PM}$ \\
$5: 00 \mathrm{PM}$ & $6: 00 \mathrm{PM}$ \\
$6: 00 \mathrm{PM}$ & $7: 00 \mathrm{PM}$ \\
$7: 00 \mathrm{PM}$ & \\
$8: 00 \mathrm{PM}$ & \\
\hline
\end{tabular}

Table 8. South window one Dec 22

\begin{tabular}{|c|c|}
\hline timing & day light through window \\
\hline 7:00 AM & \\
8:00 AM & \\
$9: 00 \mathrm{AM}$ & \\
$10: 00 \mathrm{AM}$ & \\
$11: 00 \mathrm{AM}$ & \\
$12: 00 \mathrm{PM}$ & \\
$1: 00 \mathrm{PM}$ & \\
$2: 00 \mathrm{PM}$ & \\
$3: 00 \mathrm{PM}$ & $3: 00 \mathrm{PM}$ \\
$4: 00 \mathrm{PM}$ & $4: 00 \mathrm{PM}$ \\
$5: 00 \mathrm{PM}$ & $5: 04 \mathrm{PM}$ \\
$6: 00 \mathrm{PM}$ & \\
$7: 00 \mathrm{PM}$ & \\
$8: 00 \mathrm{PM}$ & \\
\hline
\end{tabular}

Table 9. window June 22. North Facing

\begin{tabular}{|c|c|}
\hline timing & day light through window \\
\hline $6: 00 \mathrm{AM}$ & $6: 58 \mathrm{AM}$ \\
$7: 00 \mathrm{AM}$ & $7: 00 \mathrm{AM}$ \\
$8: 00 \mathrm{AM}$ & $8: 00 \mathrm{AM}$ \\
$9: 00 \mathrm{AM}$ & $9: 00 \mathrm{AM}$ \\
$10: 00 \mathrm{AM}$ & \\
$11: 00 \mathrm{AM}$ & \\
$12: 00 \mathrm{PM}$ & \\
$1: 00 \mathrm{PM}$ & \\
$2: 00 \mathrm{PM}$ & \\
$3: 00 \mathrm{PM}$ & \\
$4: 00 \mathrm{PM}$ & \\
$5: 00 \mathrm{PM}$ & \\
$6: 00 \mathrm{PM}$ & $6: 00 \mathrm{PM}$ \\
$7: 00 \mathrm{PM}$ & $7: 00 \mathrm{PM}$ \\
$8: 00 \mathrm{PM}$ & $8: 11 \mathrm{PM}$ \\
\hline
\end{tabular}

Table 10. window 3a June 22. East Facing

\begin{tabular}{|c|c|}
\hline timing & day light through window \\
\hline $6: 00 \mathrm{AM}$ & $6: 58 \mathrm{AM}$ \\
$7: 00 \mathrm{AM}$ & $7: 00 \mathrm{AM}$ \\
$8: 00 \mathrm{AM}$ & $8: 00 \mathrm{AM}$ \\
$9: 00 \mathrm{AM}$ & $9: 00 \mathrm{AM}$ \\
$10: 00 \mathrm{AM}$ & $10: 00 \mathrm{AM}$ \\
$11: 00 \mathrm{AM}$ & $11: 00 \mathrm{AM}$ \\
$12: 00 \mathrm{PM}$ & $12: 00 \mathrm{PM}$ \\
$1: 00 \mathrm{PM}$ & \\
$2: 00 \mathrm{PM}$ & \\
$3: 00 \mathrm{PM}$ & \\
$4: 00 \mathrm{PM}$ & \\
$5: 00 \mathrm{PM}$ & \\
$6: 00 \mathrm{PM}$ & \\
$7: 00 \mathrm{PM}$ & \\
$8: 00 \mathrm{PM}$ & \\
\hline
\end{tabular}


Table 11. East window two Dec 22

\begin{tabular}{|c|c|}
\hline timing & day light through window \\
\hline $7: 00 \mathrm{AM}$ & \\
$8: 00 \mathrm{AM}$ & \\
9:00 AM & \\
$10: 00 \mathrm{AM}$ & \\
$11: 00 \mathrm{AM}$ & \\
$12: 00 \mathrm{PM}$ & $12: 00 \mathrm{PM}$ \\
$1: 00 \mathrm{PM}$ & $1: 00 \mathrm{PM}$ \\
$2: 00 \mathrm{PM}$ & $2: 00 \mathrm{PM}$ \\
$3: 00 \mathrm{PM}$ & $3: 00 \mathrm{PM}$ \\
$4: 00 \mathrm{PM}$ & $4: 00 \mathrm{PM}$ \\
$5: 00 \mathrm{PM}$ & $5: 04 \mathrm{PM}$ \\
$6: 00 \mathrm{PM}$ & \\
$7: 00 \mathrm{PM}$ & \\
$8: 00 \mathrm{PM}$ & \\
\hline
\end{tabular}

Table 12. East window two June 22

\begin{tabular}{|c|c|}
\hline timing & day light through window \\
\hline $6: 00 \mathrm{AM}$ & $6: 58 \mathrm{AM}$ \\
$7: 00 \mathrm{AM}$ & $7: 00 \mathrm{AM}$ \\
$8: 00 \mathrm{AM}$ & $8: 00 \mathrm{AM}$ \\
$9: 00 \mathrm{AM}$ & $9: 00 \mathrm{AM}$ \\
$10: 00 \mathrm{AM}$ & $10: 00 \mathrm{AM}$ \\
$11: 00 \mathrm{AM}$ & $11: 00 \mathrm{AM}$ \\
$12: 00 \mathrm{PM}$ & $12: 00 \mathrm{PM}$ \\
$1: 00 \mathrm{PM}$ & \\
$2: 00 \mathrm{PM}$ & \\
$3: 00 \mathrm{PM}$ & \\
$4: 00 \mathrm{PM}$ & \\
$5: 00 \mathrm{PM}$ & \\
$6: 00 \mathrm{PM}$ & \\
$7: 00 \mathrm{PM}$ & \\
$8: 00 \mathrm{PM}$ & \\
\hline
\end{tabular}

Table 13. window two June 22. South Facing

\begin{tabular}{|c|c|}
\hline timing & day light through window \\
\hline $7: 00 \mathrm{AM}$ & \\
$8: 00 \mathrm{AM}$ & \\
$9: 00 \mathrm{AM}$ & $10: 00 \mathrm{AM}$ \\
$10: 00 \mathrm{AM}$ & $11: 00 \mathrm{AM}$ \\
$11: 00 \mathrm{AM}$ & $12: 00 \mathrm{PM}$ \\
$12: 00 \mathrm{PM}$ & $1: 00 \mathrm{PM}$ \\
$1: 00 \mathrm{PM}$ & $2: 00 \mathrm{PM}$ \\
$2: 00 \mathrm{PM}$ & $3: 00 \mathrm{PM}$ \\
$3: 00 \mathrm{PM}$ & \\
$4: 00 \mathrm{PM}$ & \\
$5: 00 \mathrm{PM}$ & \\
$6: 00 \mathrm{PM}$ & \\
$7: 00 \mathrm{PM}$ & \\
$8: 00 \mathrm{PM}$ & \\
\hline
\end{tabular}

Table 14. window two Dec 22

\begin{tabular}{|c|c|}
\hline timing & day light through window \\
\hline $7: 00 \mathrm{AM}$ & $7: 00 \mathrm{AM}$ \\
$8: 00 \mathrm{AM}$ & $8: 00 \mathrm{AM}$ \\
$9: 00 \mathrm{AM}$ & $9: 00 \mathrm{AM}$ \\
$10: 00 \mathrm{AM}$ & $10: 00 \mathrm{AM}$ \\
$11: 00 \mathrm{AM}$ & $11: 00 \mathrm{AM}$ \\
$12: 00 \mathrm{PM}$ & $12: 00 \mathrm{PM}$ \\
$1: 00 \mathrm{PM}$ & $1: 00 \mathrm{PM}$ \\
$2: 00 \mathrm{PM}$ & $2: 00 \mathrm{PM}$ \\
$3: 00 \mathrm{PM}$ & $3: 00 \mathrm{PM}$ \\
$4: 00 \mathrm{PM}$ & $4: 00 \mathrm{PM}$ \\
$5: 00 \mathrm{PM}$ & $5: 04 \mathrm{PM}$ \\
$6: 00 \mathrm{PM}$ & \\
$7: 00 \mathrm{PM}$ & \\
$8: 00 \mathrm{PM}$ & \\
\hline
\end{tabular}

\subsection{Results and Discussion}

The house R-50 uses few passive techniques as shown in Figure 2 for the prevention of sun radiation inside the house. This is directly affecting the consumption of the electricity, as shown in table 3 to 14 . However, the drawback of this solution is that the green cover shown here invites a lot of insects and mosquitoes.

Simple techniques are used in the second house R-50 that resulted in radical reductions in the consumption of electricity. The huge fenestration of ten meter-square; provides a natural external curtain to prevent radiation. This also reduces the temperature of the house, because there is a continuous process of photosynthesis around the building. This provides natural ventilation and production of oxygen for the house. Consequently, it results in reduction of energy consumption.

The Figure 2 shows the plan of P-120. The sun-path diagram is traced on every window and the yellow shaded area shows the hours of the sun throughout the year. The yellow arrows indicate the orientation of every window. The fenestration size on every elevation varies from 8 meter-square to 12 meter-square, which is very high. They are not insulated properly from outside.

It has been studied that in the morning the sun shifts to the areas from east to west where the morning activities are carried out. In the afternoon, the sun is in the southern side, where the kitchen and dining area is located, where it becomes difficult to work in that area and thus it rises the temperature in the dining area. Then in the evening, when it sunsets, the sun moves to west making the living area extremely hot.

Thus, it is observed that all the time the parallel sunlight enters the house throughout the day, compelling the people to take advantage of air-conditioning facilities. As a result the electricity consumption by the occupants to attain comfort increases. 
Above Table 9to 14 there is the comparison of the radiation penetration through east façade and south façade. It can be noted that in East façade the radiation is maximum in the morning whereas in the second graph the radiation is maximum in the mid day.

\section{Comparison of Houses P-120 and Eco House through Radiation for 22nd December}

Radiation penetration through fenestration is shown in this comparison of the two houses P-120 and the Eco House. The difference in the radiation penetration on $22^{\text {nd }}$ December. Where former house has total of $289209 \mathrm{~W} / \mathrm{m}^{2}$, and the latter has total radiation of $11548 \mathrm{~W} / \mathrm{m}^{2}$.

\subsection{Redefining Comfort Standards}

- Up until now the comfort standards have been concerned with accurate measurement and definition of indoor conditions on the basis that this equates with accurate measurement of ,comfort", e.g. house one, P-120

- In the process it has become accepted that tightly controlled conditions equate with better comfort

- Analysis of field surveys and adaptive comfort theory have made it clear that whilst close control is one way of achieving comfort it is not the only way

- At the same time close control is an expensive strategy in terms of energy

- New standards are needed which reflect the need for low-carbon futures

- We want to define a standard which encourages NOT high energy buildings but LOW energy buildings

- They must be comfortable or they are not sustainable

- There is no temperature at which everyone will feel comfortable, comfort is a psychological state defined by climate, culture and economic circumstances

This is again a difference of $25 \%$, as shown in the chapter five. There is a total for the radiation on all four elevations for present house P-120.

\section{Conclusion}

This paper basically deals with the issue of comfortable living. A living can satisfy the emotional feelings of the occupants by two ways. Firstly, by the aesthetics i.e. the tangible aspects, and secondly, by the monetary compensation i.e. the economical energy consumption aspects of an affordable accommodation.

The core theme of Eco House, is discussed here as a viable alternative of low carbon, environmental friendly, and healthy living. The beauty of this solution is its sustainability. Not only this solution provides low energy consumption for the present dwellers but also this is considered to be essential for preserving resources for the future generations.

The concept of Eco House is explained well in research statement, i.e.

"An Eco-House can provide same or even more (i.e. variable degree) level of comfort for residential buildings as that of high energy consumption houses".

This research has proved the above statement through various comparisons provided in detail in different chapters. To strengthen this idea the dissertation was primarily focused upon the residential sector. There are three different examples discusses individually. The two houses are non eco houses. One of them uses passive solar techniques. However, the third house is an Eco House design, proposed by the author of this dissertation. This idea is not the new one, and the three case studies from three different parts of the world are explained at length to support this argument.

The research has provided in detail the Eco-House design proposal for which creative design

The results are drawn on the basis of the electricity bills comparisons of all the three types of houses discussed in the dissertation. Moreover the calculations of radiation recorded for all the houses; on June 22nd and on December 22nd respectively; have provided substantial material to help analyze the findings based upon the facts.

Although there are certain limitations of the Eco-Houses, yet on the average it is the most suitable option that the architects of today should pay attention towards while designing the new houses. The concept will even further be explored in future studies by the author and the invitation is open to all the architecture students to discuss and debate this subject.

\section{REFERENCES}

[1] S. N Christian The concept of dwelling, New York, Rizzoli, 1985, pp 110

[2] Gaston B, The poetics of space, NewYork, 1995, pp 51

[3] The national Energy Conservation Center, Design Manual for energy efficient buildings in Pakistan, Enercon, Islamabad, 1990, pp 65

[4] Roaf. S and Fergus. N, Adaptive Standards for Thermal Comfort in Buildings, Heriot Watt University, International Seminar, Saint John International University, Torino Italy, Sustainablity for building Renovation and Restoration, 2009, pp21

[5] Narenda K. B, Passive Building Design, A handbook of Natural Climate Control, Netherland, 1994, pp 133

[6] Green economy and governance in cities: assessing good governance in key urban economic processes Journal of Cleaner Production, Volume 58, 1 November 2013, Pages 138-152

Jose A. Puppim de Oliveira, Christopher N.H. Doll, Osman Balaban, Ping Jiang, Magali Dreyfus, Aki Suwa, Raquel 
Moreno-Peñaranda, Puspita Dirgahayani.

[7] Towards the real green revolution? Exploring the conceptual dimensions of a new ecological modernisation of agriculture that could 'feed the world' Original Research Article Global Environmental Change, Volume 21, Issue 2, May 2011, Pages 441-452, L.G. Horlings, T.K. Marsden.

[8] Challenges of the Unknown Building Material Substances for Greener Adaptation Projects Original Research Article Procedia - Social and Behavioral Sciences, Volume 68, 19 December 2012, Pages 53-62, Zarina Isnin, Sabarinah Sh. Ahmad, Zaharah Yahya.
[9] Chapter 6 - Sustainable Building for a Green and an Efficient Built Environment: New and Existing Case Studies in Dubai Sustainability, Energy and Architecture, 2013, Pages 131-170, Mohsen Aboulnaga.

[10] Capacity-building or social construction? Explaining Sweden's shift towards ecological modernisation Geoforum, Volume 31, Issue 1, February 2000, Pages 21-32, Lennart J. Lundqvist 